\title{
Palaeoenvironment of Maastrichtian ostracods from ODP Holes 1049B, 1050C and 1052E in the Western North Atlantic
}

\author{
STEFAN MAJORAN \\ Department of Earth Sciences-Marine Geology, Earth Sciences Centre, Gothenburg University, Box 460, SE 40530 Gothenburg, Sweden.
}

\begin{abstract}
The Maastrichtian ostracods recovered from ODP Holes 1049B, 1050C and 1052E on the Blake Nose, Western North Atlantic, are investigated. The three sites are located on a depth transect encompassing middle to lower bathyal, Late Cretaceous palaeodepths. Fourteen samples ranging in age from early to late Maastrictian are investigated from Hole $1052 \mathrm{E}$, which is the shallowest site. The early Maastrichtian G. falsostuarti-G. gansseri Zone of Hole 1052E yields rare ostracods. The species richness, abundance and faunal density are on average considerably higher in the late Maastrichtian $R$. fructicosa and A. mayaroensis Zones of Hole 1052E, possibly, at least partly, as a result of palaeoceanographical changes that were also responsible for the disappearance of the inoceramid bivalves at this location. A palaeobathymetrical comparsion among the late Maastrichtian ostracod assemblages recorded from Holes 1049B, 1050C and 1052E shows that the faunal density and mean number of taxa are inversely correlated with palaeodepth; however, the dominance of the platycopid genus Cytherella increases with palaeodepth. A dominance of platycopids may signify environmental stress related to low oxygen content. The dominance of the benthic foraminifer Nuttalides trumpeyi in the Late Cretaceous of Holes 1049B and $1050 \mathrm{C}$ provides additional evidence of oxygen deficiency. From a total of 28 genera recorded from Holes $1049 \mathrm{~B}, 1050 \mathrm{C}$ and 1052E, 14 were previously recorded from Hole $689 \mathrm{~B}$, a high latitude hole in the Southern Ocean, and show that many ostracod genera display a wide latitudinal distribution in the Late Cretaceous deep sea, although more geographically restricted genera are also present, analogous with modern and Tertiary oceans. J. Micropalaeontol. 18(2): 125-136 December 1999.
\end{abstract}

\section{INTRODUCTION}

During the Maastrichtian, world-wide biotic changes occurred which included the global extinction of the inoceramid bivalves (MacLeod, 1994; MacLeod et al., 1996) and the tropical rudist reef faunas (Johnson \& Kauffman, 1990). There were also major latitudinal shifts in the distribution of planktonic foraminifers and calcareous nannoplankton (Huber \& Watkins, 1992).

According to Saltzman \& Barron (1982), the formation of Late Cretaceous deep water occurred both in low latitude marginal seas by evaporation forming warm, saline bottom waters and at high latitudes by the subsidence of cool surface water. For the Maastrichtian, Barrera \& Huber (1990) and Barrera et al. (1997) showed that planktonic and benthic foraminiferal $\delta^{18} \mathrm{O}$ isotopes provide evidence of a trend of cooling of surface and intermediate waters between 74 and 68 Ma at high southern latitudes. Superimposed on this trend, there is isotopic evidence of a temporarily short event in the early Maastrichtian (between 71 and $70 \mathrm{Ma}$ ) during which the oceanic circulation may have become more typical of the Recent thermohaline pattern with an intensified production of cool, well-oxygenated bottom and intermediate waters at high latitudes (MacLeod \& Huber, 1996; Barrera et al., 1997). Before and after this event, the oceanic circulation was probably more typical of the Late Cretaceous pattern with a stronger influence of warm saline plumes formed at low latitudes (Barrera et al., 1997). According to MacLeod (1994), the last inoceramids were adapted to warm, oxygen-deficient conditions. Their extinction was possibly, at least partly, a consequence of such changes in oceanic circulation as occurred between 71 and $70 \mathrm{Ma}$ (Macleod, 1994). In addition, an increase in the ${ }^{87} \mathrm{Sr} /{ }^{86} \mathrm{Sr}$ ratio of sea water at $71 \mathrm{Ma}$ indicates intensified continental weathering, and may be an expected result of a global regression
(Barrera et al., 1997). Such a regression may have drained the low- and mid-latitude epicontinental seas and temporarily reduced the formation of warm, saline bottom waters. The extinction of rudist reefs has been related to the disappearance of hypersaline surface water produced in shallow epicontinental seas (Johnson \& Kauffman, 1990).

Little is known about how the Maastrichtian palaeoceanographic perturbations that occurred between 74 and $68 \mathrm{Ma}$ affected nannofossils, benthic foraminifers and ostracods at lower latitudes. Low latitude sites with good recovery and preservation through this time interval are rare. One of the objectives of Leg 171B, which included five sites drilled along a depth transect on the Blake Nose in the Western North Atlantic, was to study patterns of turnover in middle Maastrichtian microbiota. Benson et al. $(1984,1985)$ have previously shown the usefulness of ostracod studies in detecting major palaeoceanographic changes in the Cenozoic world ocean. The objective of the present preliminary study is partly to describe faunal changes in middle bathyal ostracod assemblages throughout the Maastrichtian at Site 1052. The intention is also to describe late Maastrichtian palaeobathymetrical changes in the composition of bathyal ostracod assemblages along a depth transect on the Blake Nose encompassing ODP Sites 1049, 1050 and 1052 (Fig. 1).

Swain (1978) and Guernet (1982) have previously described Cretaceous and Palaeogene ostracods, respectively, from Site 390 (DSDP Leg 44) on the Blake Nose. Previous studies, partly or completely focused on Late Cretaceous deep-sea ostracods (i.e. from a palaeodepth $>500 \mathrm{~m}$ ) of the Atlantic and Southern Oceans include Benson $(1975,1977)$, Benson et al. $(1984,1985)$, Damotte (1979, 1988), Dingle (1981), Swain (1973, 1978, 1983), Majoran et al. (1997), Majoran et al. (1998) and Majoran \& Widmark (1998). 


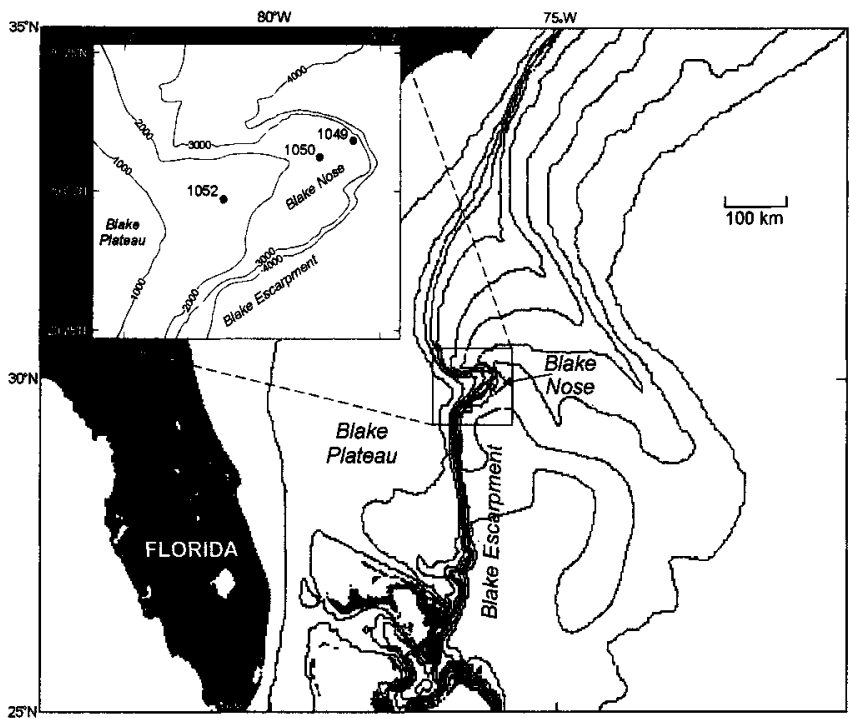

Fig. 1. Location map of Sites 1049, 1050 and 1052 on the Blake Nose, Western North Atlantic.

\section{METHODS}

A total of 24 Maastrichtian samples $\left(20 \mathrm{~cm}^{3}\right.$ each) were studied from ODP Holes 1049B, 1050C and 1052E (see Table 1). All samples were dried and subsequently immersed in deionized water and placed on a rotary table for $24 \mathrm{~h}$. They were then washed over a $63 \mu \mathrm{m}$ sieve and dried. The dried samples were sieved through a $125 \mu \mathrm{m}$ sieve. All ostracods retained from this sieve fraction were picked under a binocular microscope and arranged on faunal slides. Almost all the specimens picked consisted of single valves or valve fragments. One valve was counted as one specimen, as were identifiable broken specimens that were greater than half the size of a complete valve. Broken specimens less than half the size of a complete valve were counted as fragments. The specimens were mainly identified to the level of the species, although some featureless genera, difficult to separate at specific level, were lumped together into multispecific categories, e.g. Cytherella spp., Krithe spp. and Argilloecia spp. The figured specimens (Plates 1 and 2) were coated with gold and photographed under a Zeiss Digital Scanning Microscope DSM 940 at the Department of Marine Geology, Earth Sciences Centre, Gothenburg University. All
Table 1. Samples of ODP Holes 1052E, 1050C and 1049B investigated for ostracods.

\begin{tabular}{lllllll}
\hline Hole & Section & $\begin{array}{l}\text { Interval } \\
\text { (cm) }\end{array}$ & $\begin{array}{l}\text { Depth } \\
\text { (mbsf) }\end{array}$ & $\begin{array}{l}\text { Weight } \\
(\mathrm{g})\end{array}$ & $\mathrm{N}$ & $\mathrm{F}$ \\
\hline $1052 \mathrm{E}$ & $20-1$ & $100-103$ & 320.30 & 23.64 & 93 & 28 \\
$1052 \mathrm{E}$ & $20-4$ & $111-114$ & 324.91 & 17.63 & 108 & 18 \\
$1052 \mathrm{E}$ & $20-6$ & $93-96$ & 327.73 & 29.51 & 123 & 42 \\
$1052 \mathrm{E}$ & $22-1$ & $112-115$ & 339.72 & 39.95 & 175 & 39 \\
$1052 \mathrm{E}$ & $23-2$ & $117-120$ & 350.97 & 24.15 & 17 & 18 \\
$1052 \mathrm{E}$ & $24-1$ & $109-113$ & 358.99 & 17.67 & 1 & 1 \\
$1052 \mathrm{E}$ & $25-1$ & $113-117$ & 368.63 & 21.48 & 24 & 0 \\
$1052 \mathrm{E}$ & $26-1$ & $138-143$ & 378.48 & 46.99 & 7 & 4 \\
$1052 \mathrm{E}$ & $27-1$ & $98-102$ & 387.68 & 30.26 & 46 & 24 \\
$1052 \mathrm{E}$ & $29-1$ & $121-125$ & 407.11 & 31.38 & 1 & 1 \\
$1052 \mathrm{E}$ & $31-1$ & $116-120$ & 426.26 & 36.00 & 4 & 0 \\
$1052 \mathrm{E}$ & $31-\mathrm{cc}$ & $0-3$ & 434.70 & 32.20 & 3 & 1 \\
$1052 \mathrm{E}$ & $34-1$ & $74-77$ & 454.64 & 23.16 & 1 & 0 \\
$1052 \mathrm{E}$ & $35-1$ & $110-113$ & 464.70 & 27.84 & 2 & 1 \\
$1050 \mathrm{C}$ & $11-1$ & $102-105$ & 409.71 & 42.57 & 25 & 15 \\
$1050 \mathrm{C}$ & $11-1$ & $146-149$ & 410.15 & 44.85 & 17 & 8 \\
$1050 \mathrm{C}$ & $11-2$ & $23-27$ & 410.42 & 43.75 & 22 & 5 \\
$1050 \mathrm{C}$ & $11-2$ & $52-55$ & 410.71 & 54.68 & 42 & 11 \\
$1050 \mathrm{C}$ & $11-2$ & $75-78$ & 410.94 & 51.52 & 11 & 7 \\
$1049 \mathrm{~B}$ & $8-3$ & $85-87$ & 112.85 & 29.38 & 1 & 2 \\
$1049 \mathrm{~B}$ & $8-4$ & $25-27$ & 113.75 & 28.54 & 5 & 6 \\
$1049 \mathrm{~B}$ & $8-4$ & $115-117$ & 114.65 & 27.11 & 1 & 0 \\
$1049 \mathrm{~B}$ & $8-5$ & $10-12$ & 115.10 & 25.89 & 7 & 1 \\
$1049 \mathrm{~B}$ & $8-5$ & $110-115$ & 116.10 & 39.36 & 11 & 0 \\
\hline
\end{tabular}

$N$ represents number of identified specimens; $F$ represents number of unidentified fragments.

figured specimens and faunal slides are stored at this location. The figured specimens are stored under the designation codes DMGUG.N.At1.1-42.

The ostracod valve accumulation rate (OVAR) (Majoran et al., 1997) was taken as a measure of the faunal density of ostracods, or more precisely the number of ostracods produced per unit area and unit time. The OVAR (the number of valves and unidentified fragments per $\mathrm{cm}^{2}$ and $\mathrm{kyr}$ ) was calculated as $N D S$, where $N$ is the number of valves and unidentified fragments per gram of sediment, $D$ is the dry density of the sediment in $\mathrm{g} / \mathrm{cm}^{3}$ and $S$ is the sedimentation rate in $\mathrm{cm} / \mathrm{kyr}$. The OVAR corresponds to the benthic foraminifer accumulation rate (BFAR) of Herguera \& Berger (1991), which has been suggested as a proxy for palaeoproductivity. The BFAR

\section{Explanation of Plate 1}

fig. 1. Dutoitella? sp., sample 171B-1049B-8H-5, 110-115 cm, LV, Juv., $\times 66$, DMGUG.N.Atl.1. fig. 2. Cardobairdia sp., sample 171B-1049B-8H-4, 25-27 cm, RV, ×66, DMGUG.N.Atl.2. fig. 3. Pterygocythereis sp., sample 171B-1050C-11R-1, 146-149 cm, LV, ×38, DMGUG.N.Atl.3. fig. 4. Bairdia sp., sample 171B-1052E-22R-1, 112-115 cm, RV, Juv., ×62, DMGUG.N.Atl.4. fig. 5. Abyssocypris? sp., sample 171B-1052E-27R-1, 98$102 \mathrm{~cm}$, LV, Juv., $\times 86$, DMGUG.N.At1.5. fig. 6. Apateloschizocythere? sp., sample 171 B-1052E-20R-6, 93-96 cm, LV, Juv., $\times 108$, DMGUG.N.Atl.6. fig. 7. Argilloecia sp., sample 171B-1052E-20R-6, 93-96 cm, LV, $\times 76$, DMGUG.N.At1.7. fig. 8. Aversovalva sp. 1, sample 171B-1052E-20R-6, 93$96 \mathrm{~cm}, \mathrm{LV}, \times 113$, DMGUG.N.Atl.8. fig. 9. Aversovalva sp. 2, sample 171B-1052E-25R-1, $113-117 \mathrm{~cm}, \mathrm{LV}, \times 113$, DMGUG.N.Atl.9. fig. 10. Bairdia sp. 1, sample 171B-1052E-20R-6, 93-96 cm, RV, ×24, DMGUG.N.Atl.10. fig. 11. Bairdia sp. 2, sample 171B-1052E-20R-4, 111-114 cm, LV, Juv., $\times 52$, DMGUG.N.Atl.11. fig. 12. 'Brachycythere' sp., sample 171 B-1052E-20R-6, $93-96 \mathrm{~cm}, \mathrm{LV}, \times 47$, DMGUG.N.Atl.12. fig. 13. Bythoceratina sp., Sample 171B-1052E-22R-1, 112-115 cm, RV, $\times 43$, DMGUG.N.Atl.13. fig. 14. Bythocypris sp., sample 171B-1052E-20R-6, 93-96 cm, RV, Juv., $\times 54$, DMGUG.N.Atl.14. fig. 15. Palmoconcha sp., sample 171B-1052E-27R-1, 98-102 cm, LV, Juv., ×119, DMGUG.N.Atl.15. fig. 16. Cytherella sp., sample 171B-1052E-22R-1, 112-115cm, RV, $\times 38$, DMGUG.N.Atl.16. fig. 17. Cytheropteron sp., sample 171B-1052E-22R-1, 112-115cm, RV, Juv., $\times 94$, DMGUG.N.Atl.17. fig. 18. Eucythere sp. 2, sample 171B-1052E-22R-1, 112-115 cm, LV, Juv., ×94, DMGUG.N.Atl.18. fig. 19. Eucythere cf. circumcostata Whatley and Coles, 1987, sample 171B-1052E-22R-1, 112-115cm, RV, Juv., $\times 113$, DMGUG.N.Atl.19. fig. 20. Eucytherura sp. 1, sample 171B-1052E-22R-1, 112-115 cm, LV, ×109, DMGUG.N.Atl.20. fig. 21. Eucytheura sp. 2, Sample 171B-1052E-22R-1, 112-115cm, RV, $\times 119$, DMGUG.N.Atl.21 


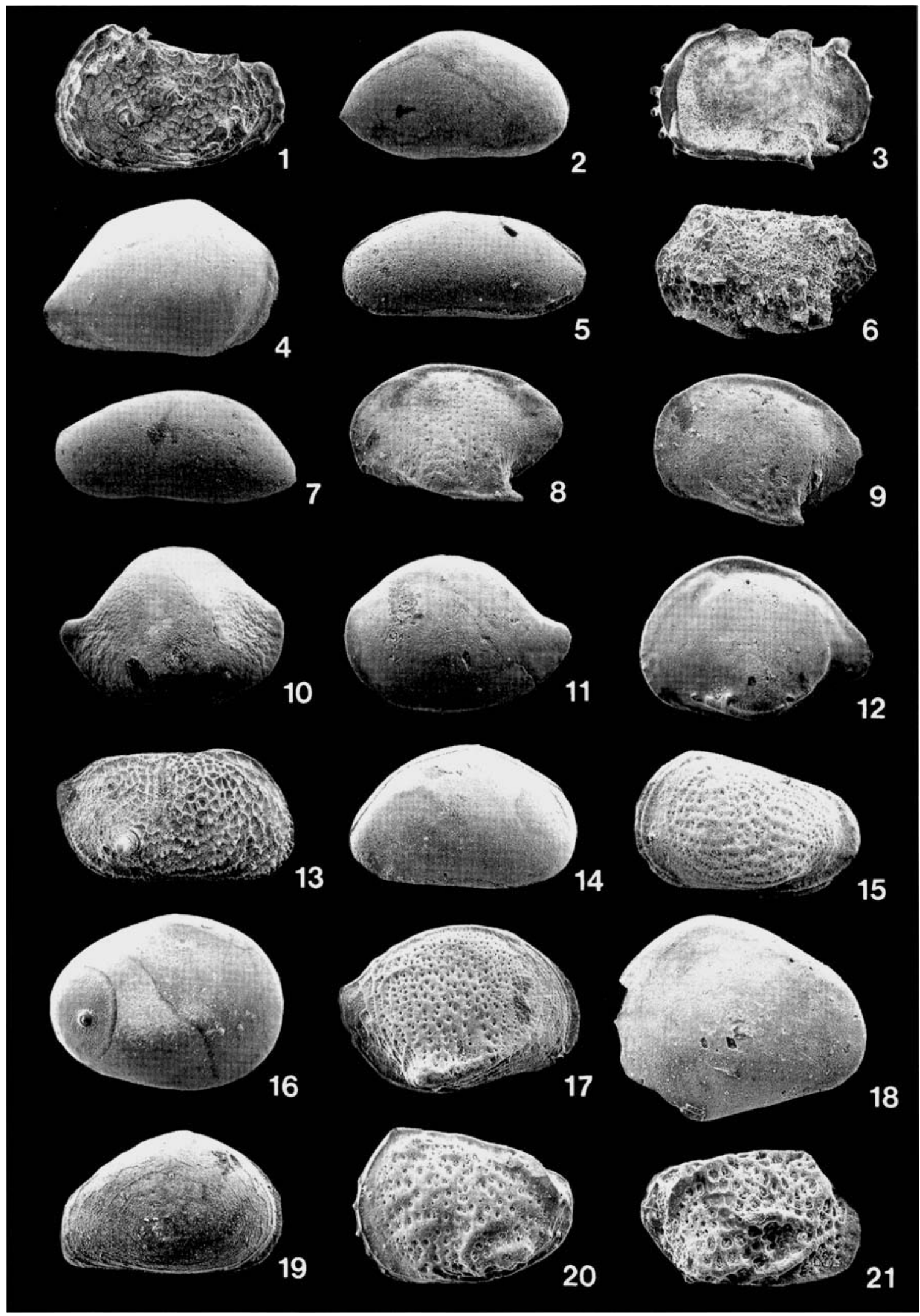




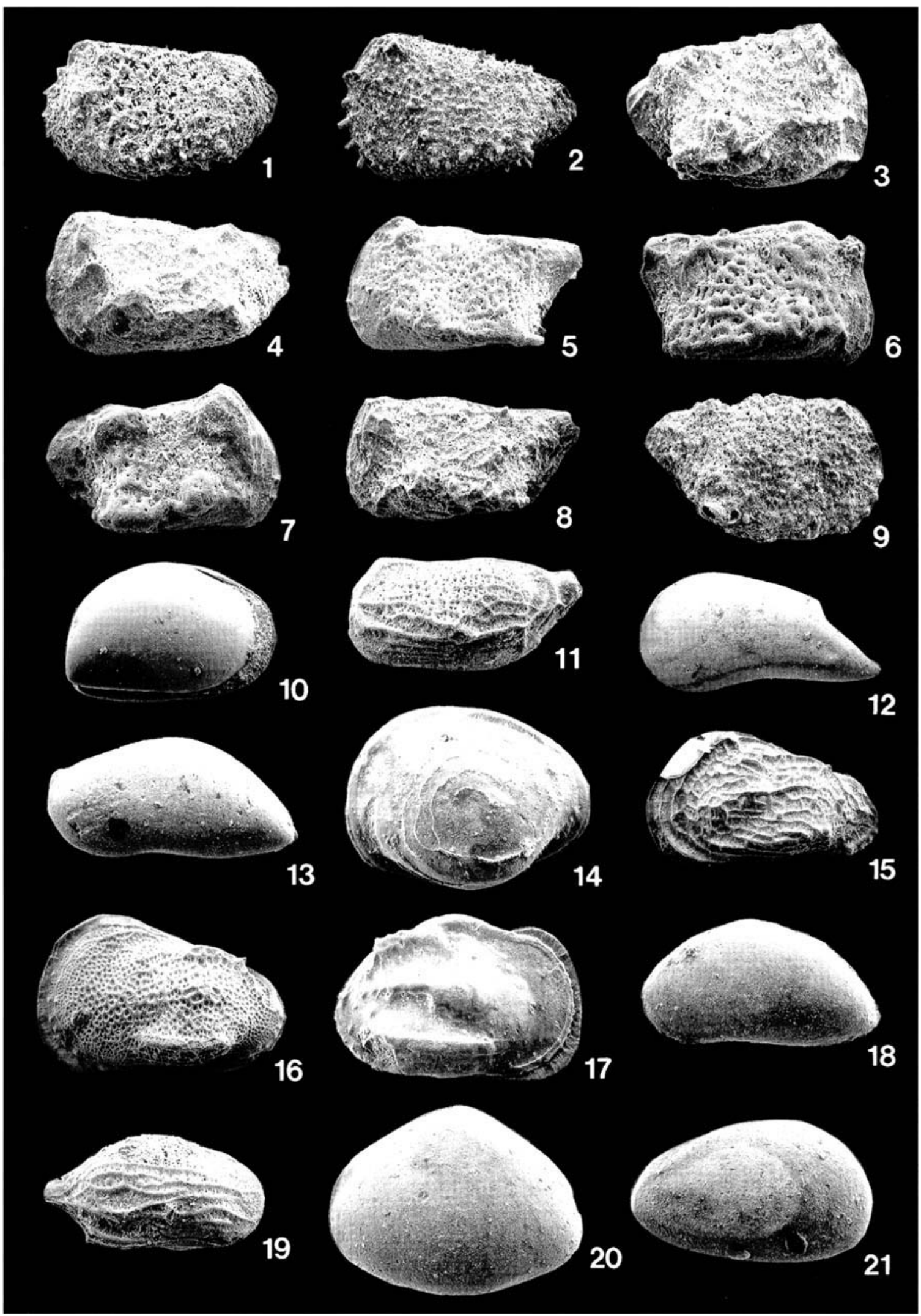


hypothesis is based on the assumption that the number of benthic foraminifera produced per $\mathrm{cm}^{2}$ and kyr is related to the supply of organic material to the seafloor which in turn is positively correlated with the productivity in the photic zone (Herguera \& Berger, 1991). An exception is in areas with a pronounced oxygen minimim zone such as the Oman Margin where Naidu \& Malmgren (1995) showed that the BFAR values were negatively correlated with the productivity of surface waters during the Holocene. They suggested that this may be due to the influence of low dissolved oxygen concentrations on benthic foraminiferal assemblages. According to Naidu \& Malmgren (1995), BFAR may not be generally taken as a measure of productivity.

\section{OSTRACOD DISTRIBUTION}

Most specimens recorded are juveniles, which makes precise taxonomic determinations difficult. Most species are represented by only a few individuals. All ostracod species recorded were blind and therefore indicative of palaeodepths exceeding 700 $800 \mathrm{~m}$ (Benson, 1975).

\section{Site 1052}

Hole $1052 \mathrm{E}\left(29^{\circ} 57.08^{\prime} \mathrm{N}, 76^{\circ} 37.61^{\prime} \mathrm{W}\right)$ was drilled on the upper part of the Blake Nose at a water depth of $1343.5 \mathrm{~m}$, being one of a suite of holes associated with the shallowest site of Leg $171 \mathrm{~B}$. It penetrated $175.8 \mathrm{~m}$ of Maastrichtian sediments, which, on the basis of lithology, can be divided into two subunits: (1) a late Maastrichtian interval of $87.0 \mathrm{~m}(1052 \mathrm{E}-18 \mathrm{R}-3,0 \mathrm{~cm}$, to $1052 \mathrm{E}-27 \mathrm{R}-2,38 \mathrm{~cm}$ ), consisting of greenish grey to light greenish grey nannofossil chalk with clay to clayey nannofossil chalk with metre-scale alternations between lighter and darker intervals; and (2) an early Maastrichtian interval of $88.8 \mathrm{~m}$ (1052E-27R-2, $38 \mathrm{~cm}$, to $1052 \mathrm{E}-36 \mathrm{R}-3,122 \mathrm{~cm}$ ), consisting dominantly of light greenish grey to very light greenish grey nannofossil chalk to nannofossil chalk. The older subunit differs from the younger by generally being lighter and more carbonaterich, by a higher frequency of bioturbated intervals and apparent slump deposits, and by the presence of inoceramid shell remains (Norris et al., 1998).

The benthic foraminifers are represented by oligotaxic faunas in the Upper Cretaceous of Site 1052. Eouvigerina subsculptura constitutes the dominant element in the benthic foraminiferal community. This species is common in high trophic levels in the
Maastrichtian of the Tethyan realm and is thus indicative of high productivity over the Blake Nose (Norris et al., 1998).

A total of 14 samples was investigated for ostracods from the Maastrichtian of Hole 1052E. Five of the samples were taken from the $G$. falsostuarti $G$. gansseri Zone, two from the $R$. fructicosa Zone and seven from the $A$. mayaroensis Zone (Table 2). The five samples of the G. falsostuarti-G. gansseri Zone (all within the lower Maastrichtian lithological subunit) are impoverished with respect to ostracods and contain mainly rare specimens of Cytherella spp. The species richness and abundance of ostracods are on average considerably higher in the nine samples of the $R$. fructicosa and $A$. mayaroensis Zones (all within the upper Maastrichtian lithological subunit) (Table 2). From these nine samples a total of 594 specimens (not fragments) were recorded and a total of 47 species identified. Many species are represented by only a few or single specimens. The most dominant taxa are Cytherella spp. (total relative abundance of $30.3 \%$ ), Krithe spp. (total relative abundance of $20.2 \%$ ) and Argilloecia sp. 1 and spp. (total relative abundance of $9.6 \%$ ). Other relatively common species are 'Brachycythere'sp., Bairdia spp., Cytheropteron spp. and Platyleberis sp. Rarer species with a total relative abundance $>1 \%$ include Aversovalva spp., Bythoceratina sp., Eucythere cf. circumcostata, Eucytherura sp. 2, Paraphysocythere sp., Imhotepia $\mathrm{sp}$. and Profundobythere? $\mathrm{sp}$. Of additional interest is the relatively high diversity of cytherurid species (six species of Eucytherura and four species of Hemiparacytheridea), although most of these species are represented by single or very few specimens.

Figure 2A shows the variation in OVAR among the samples studied from Hole 1052E. In each calculation of the OVAR, the sedimentation rate was set to $2.2 \mathrm{~cm} / \mathrm{kyr}$, which is the mean sedimentation rate for the Maastrichtian and Danian (Norris et al., 1998). In all the calculations, the dry density was set to 1.566 $\mathrm{g} / \mathrm{cm}^{3}$, which is the mean density in the interval from core section 1052E-20R-1 to 1052E-35R-1 (Norris et al., 1998). In the G. falsostuarti-G. gansseri Zone, the OVAR is very low and ranges between 0.15 and 0.43 . The OVAR increases across the zonal boundary between the $G$. falsostuarti- $G$. gansseri and $R$. fructicosa zones and reaches a value of 7.97 in the oldest sample of the $R$. fructicosa Zone (1052E-27-1: 98-102) before it decreases to 0.81 in the subsequent sample of this zone (1052E-26R-1: $138-143 \mathrm{~cm})$. The OVAR increases across the zonal boundary between the $R$. fructicosa and $A$. mayaroensis

\section{Explanation of Plate 2.}

fig. 1. Eucytherura sp. 3, sample 171B-1052E-22R-1, 112-115 cm, LV, $\times 124$, DMGUG.N.Atl.22. fig. 2. Eucytherura sp. 4, sample 171B-1052E-22R-1, 112-115 cm, LV, $\times 110$, DMGUG.N.Atl.23. fig. 3. Eucytherura sp. 5, sample 171B-1052E-25R-1, 113-117 cm, RV, $\times 134$, DMGUG.N.Atl.24. fig. 4. Eucytherura sp. 6, Sample 171B-1052E-26R-1, 138-143 cm, LV, $\times 134$, DMGUG.N.Atl.25. fig. 5. Hemiparacytheridea sp. 1, sample 171 B-1052E-20R4, 111-114 cm, LV, $\times 120$, DMGUG.N.Atl.26. fig. 6. Hemiparacytheridea sp. 2, sample 171B-1052E-20R-4, $111-114 \mathrm{~cm}$, RV, $\times 96$, DMGUG.N.Atl.27. fig. 7. Hemiparacytheridea sp. 3, sample 171B-1052E-20R-6, 93-96 cm, RV, $\times 124$, DMGUG.N.At1.28. fig. 8. Hemiparacytheridea sp. 4, sample 171B-1052E-22R-1, 112-115 cm, LV, $\times 96$, DMGUG.N.Atl.29. fig. 9. Hemiparacytheridea sp. 5, sample 171B-1052E-31R-CC, RV, $\times 110$, DMGUG.N.At1.30. fig. 10. Krithe sp., sample 171B-1052E-22R-1, 112-115 cm, RV (of carapace), Juv., $\times 96$, DMGUG.N.Atl.31. fig. 11. Mayburya pulchra Coles \& Whatley, 1989, sample 171B-1052E-27R-1, 98-102 cm, LV, $\times 110$, DMGUG.N.Atl.32. fig. 12. Paracypris sp., sample 171B-1052E-22R-1, 112-115cm, LV, $\times 82$, DMGUG.N.Atl.33. fig. 13. Argilloecia sp. 1, sample 171B-1052E-22R-1, 112-115cm, LV, $\times 89$, DMGUG.N.Atl.34. fig. 14. Paraphysocythere sp., sample 171B-1052E-22R-1, 112-115 cm, LV, $\times 129$, DMGUG.N.Atl.35. fig. 15. Imhotepia sp., sample 171B-1052E-22R-1, 112-115 cm, LV, $\times 62$, DMGUG.N.Atl.36. fig. 16. Profundobythere? sp., sample 171B-1052E-20R-6, 93-96 cm, LV, $\times 62$, DMGUG.N.At1.37. fig. 17. Phacorhabdotus sp. 3, sample 171B-1052E-20R-4, 111-114 cm, RV, $\times 62$, DMGUG.N.Atl.38. fig. 18. Propontocypris sp., sample 171B-1052E-22R-1, 112-115, LV, Juv., ×96, DMGUG.N.Atl.39. fig. 19. Semicytherura sp., sample 171B-1052E-22R-1, 112-115 cm, RV, $\times 96$, DMGUG.N.Atl.40. fig. 20. Platyleberis sp., Sample 171B-1052E-22R-1, 112-115 cm, LV, Juv., $\times 122$, DMGUG.N.At1.41. fig. 21. Unidentified sp. 1, sample 171B-1052E-22R-1, 112-115cm, RV, ×120, DMGUG.N.Atl.42. 

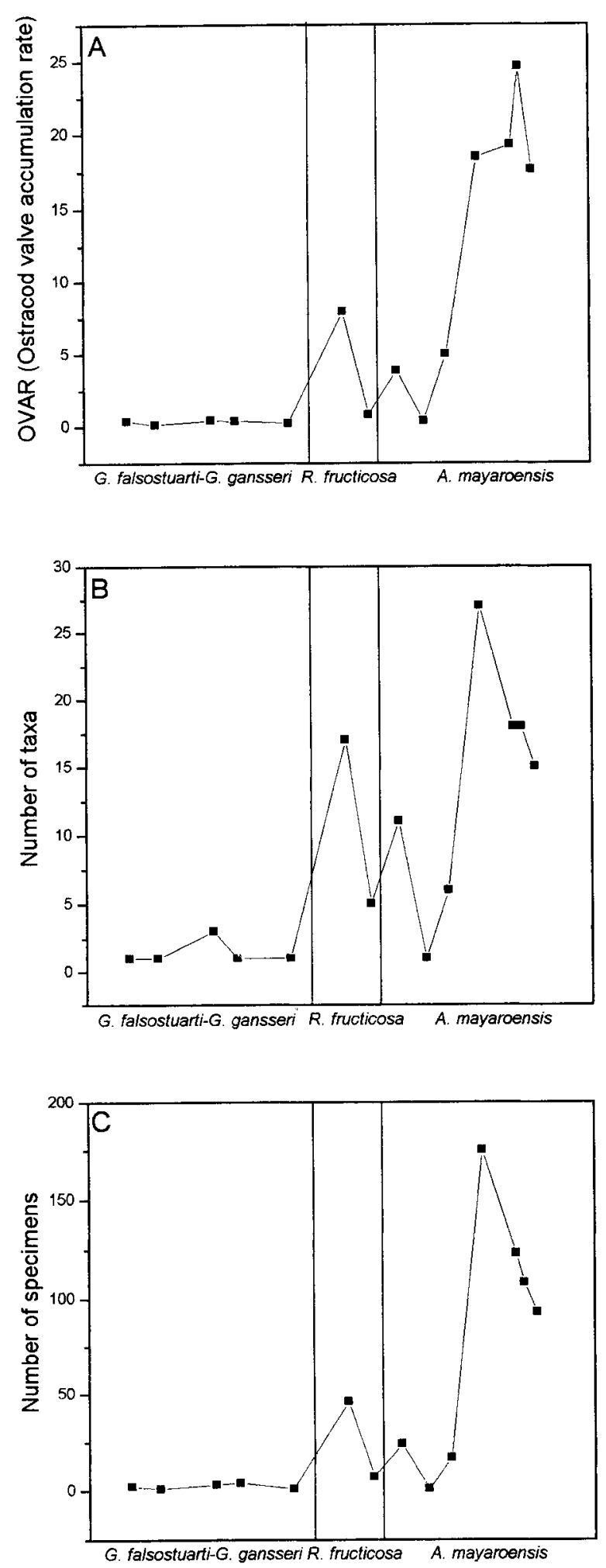

Fig. 2. Faunal analysis of the 14 samples studied from the Maastrichtian of Hole 1052E. (A) Ostracod valve accumulation rate (OVAR in number of specimens $/ \mathrm{cm}^{2} / \mathbf{k a}$ ) in each sample. (B) Number of species/taxa in each sample. (C) Number of specimens in each sample. zones and attains a value of 3.85 in the oldest sample of the $A$. mayaroensis Zone (1052E-25R-1: $113-117 \mathrm{~cm})$. The OVAR drops in the second oldest sample of this zone (1052E-24R-1: $109-113 \mathrm{~cm}$ ) to a value of 0.39 , before it gradually increases to 24.62 in the subsequent four samples of this zone. The OVAR of the youngest sample of the $A$. mayaroensis Zone is 17.63 (see Table 2; Fig. 2A).

The variation in the number of species and specimens among the samples studied in Hole 1052E follows an almost identical pattern to the variation in OVAR (Fig. 2A-C). It can possibly be inferred that the variation in OVAR is related to the variation in productivity, with relatively higher productivity in the late Maastricthian than the early Maastrichtian of Hole 1052E. Alternatively, the differences in OVAR between the early and late Maastrichtian are due to significantly lower oxygen concentrations at the sediment-water interface in the early Maastrichtian. It cannot be ruled out, however, that part of the differences observed between the early and late Maastrichtian ostracods are due to the effects of dilution from variations in the sedimentation rate. It is also possible that the more impoverished ostracod fauna of the early Maastrichtian (compared with the late Maastrichtian fauna) is a result of selective removal of taxa by winnowing or dissolution.

\section{Site 1050}

Hole $1050 \mathrm{C}\left(30^{\circ} 6.00^{\prime} \mathrm{N}, 76^{\circ} 14.10^{\prime} \mathrm{W}\right)$ was drilled at a water depth of $2296.5 \mathrm{~m}$ and represents an addendum to Holes $1050 \mathrm{~A}$ and $1050 \mathrm{~B}$. It was obtained to recover an equivalent sequence of the Cretaceous that was sampled at the shallower Site 1052. Five late Maastrichtian samples from the $A$. mayaroensis Zone were studied for ostracods from a lithological subunit consisting of nannofossil claystone, calcareous nannofossil claystone and nannofossil foraminiferal chalk. A total of 117 specimens (not fragments) were recorded and 14 different species identified (Table 3). The most abundant species are Cytherella $\mathrm{sp}(\mathrm{p})$. (total relative abundance $47.8 \%$ ), Krithe spp. (total relative abundance $23.1 \%$ ) and Argilloecia sp. 1 and spp. (total relative abundance $12.0 \%$ ). Other species are represented by only a few or single specimens. Cardobairdia sp. and Pterygocythereis sp. are two species recorded in Hole $1050 \mathrm{C}$ that were not recorded in Hole 1052E. Cardobairdia is a deep-water genus common in the Caribbean Tertiary (Van den Bold, 1974) and also elsewhere in the deep sea.

\section{Site 1049}

Site 1049 represents a reoccupation of DSDP Site 390, which was drilled on the eastern margin of the Blake Nose $10 \mathrm{~km}$ downslope from Site 1050 . It represents the deepest site of Leg 171B. Hole $1049 \mathrm{~B}\left(30^{\circ} 08.54^{\prime} \mathrm{N}, 76^{\circ} 06.73^{\prime} \mathrm{W}\right)$ was drilled at a water depth of $2670.8 \mathrm{~m}$. Five samples were studied for ostracods from the $R$. fructicosa and A. mayaroensis zones of the late Maastrichtian of this core. They were obtained from a lithological subunit characterized by greenish grey light grey, and pale green clayey nannofossil ooze and clayey nannofossil chalk which is laminated to slightly bioturbated. Ostracods were rare in these samples, with a total of 25 specimens recorded and eight species identified (Table 4). Nine unidentified fragments of ostracods were also recorded. Cytherella $\mathrm{sp}(\mathrm{p})$. is the dominant species with a total abundance of $52.0 \%$. Cardobairdia, with a 
Table 3. Maastrichtian ostracods from Hole $1050 \mathrm{C}$.

\begin{tabular}{|c|c|c|c|c|c|}
\hline Stage & \multicolumn{5}{|c|}{ MAASTRICHTIAN } \\
\hline Zone & \multicolumn{5}{|c|}{ A. mayaroensis } \\
\hline Polarity interval & \multicolumn{5}{|c|}{ C30N } \\
\hline Site-Hole & \multicolumn{5}{|c|}{$1050 \mathrm{C}$} \\
\hline Core-section & 11R-2 & $11 \mathrm{R}-2$ & $11 \mathrm{R}-2$ & $11 \mathrm{R}-1$ & $11 R-1$ \\
\hline TaxonVInterval (cm) & $75-78$ & $52-55$ & $23-27$ & $146-149$ & $102-105$ \\
\hline Krithe spp. & 7 & 7 & 8 & 1 & 4 \\
\hline Argilloecia sp. 1 & 1 & 1 & 1 & 2 & 2 \\
\hline Argilloocia spp. & 1 & 1 & & 1 & 4 \\
\hline Cardobairdia sp. & 1 & & & 1 & \\
\hline Platyleberis sp. & 1 & & 1 & 1 & \\
\hline $\begin{array}{l}\text { Cytherella sp(p). } \\
\text { "Brachycythere" sp }\end{array}$ & & $\begin{array}{c}26 \\
4\end{array}$ & 11 & $\begin{array}{l}7 \\
1\end{array}$ & 12 \\
\hline Bairdia sp. 1 & & 1 & & 1 & \\
\hline Paraphysocythere sp. & & 1 & & & \\
\hline Eucythere sp. 2 & & 1 & 1 & & \\
\hline $\begin{array}{l}\text { Pterygocythereis sp. } \\
\text { Cytheropteron spp. }\end{array}$ & & & & $\begin{array}{l}1 \\
1\end{array}$ & 1 \\
\hline $\begin{array}{l}\text { Protundobythere sp. } \\
\text { Eucytherura sp. } 7\end{array}$ & & & & & $\begin{array}{l}1 \\
1\end{array}$ \\
\hline Unidentified fragments & 7 & 11 & 5 & 8 & 15 \\
\hline $\begin{array}{l}\text { Number of specimens } \\
\text { (not fragments) }\end{array}$ & 11 & 42 & 22 & 17 & 25 \\
\hline $\begin{array}{l}\text { Ostracod valve } \\
\text { accumulation rate } \\
\text { (OVAR) }\end{array}$ & 0.95 & 2.64 & 1.68 & 1.52 & 2.56 \\
\hline Number of taxa & 5 & 8 & 5 & 10 & 7 \\
\hline
\end{tabular}

Table 4. Maastrichtian ostracods from Hole 1049B.

\begin{tabular}{|c|c|c|c|c|c|}
\hline Stage & \multicolumn{5}{|c|}{ MAASTRICHTIAN } \\
\hline Zones & \multicolumn{5}{|c|}{ R. fructicosa-A. mayaroensis } \\
\hline Polarity interval & \multicolumn{5}{|c|}{ C30N? } \\
\hline Site-Hole & \multicolumn{5}{|c|}{$1049 \mathrm{~B}$} \\
\hline Core-section & $8 \mathrm{P}-5$ & 8R-5 & 8R-4 & BR-4 & 8R-3 \\
\hline Genus|Interval (cm) & 110-115 & $10-12$ & 115-117 & $25-27$ & 85-87 \\
\hline Cardobairdla sp. & 1 & & & 2 & 1 \\
\hline Cytherella $\mathrm{sp}(\mathrm{p})$. & 6 & 3 & 1 & 3 & \\
\hline Bairdia sp. juv. & 1 & 1 & & & \\
\hline Dutoitella? sp. juv. & 1 & & & & \\
\hline Phacorhabdotus sp.4 & 1 & & & & \\
\hline Platyleberis sp. & 1 & & & & \\
\hline Pterygocythereis sp. & & 2 & & & \\
\hline Krithe spp. & & 1 & & & \\
\hline Unidentified fragments & & 1 & & 6 & 2 \\
\hline $\begin{array}{l}\text { Number of specimens } \\
\text { (not fragments) }\end{array}$ & 11 & 7 & 1 & 5 & 1 \\
\hline $\begin{array}{l}\text { Ostracod valve } \\
\text { accumulation rate } \\
\text { (OVAR) }\end{array}$ & 0.63 & 0.16 & 0.02 & 0.21 & 0.05 \\
\hline Number of taxa & 6 & 4 & 1 & 2 & 1 \\
\hline
\end{tabular}

total of four specimens and a total relative abundance of $16 \%$, is the second most abundant species. Other species are represented by one or two specimens only.
A PALAEOBATHYMETRIC COMPARISON OF THE LATE MAASTRICHTIAN OSTRACOD FAUNAS OF SITES 1049, 1050 AND 1052

On the basis of benthic foraminifers, Norris et al. (1998) estimated the Late Cretaceous palaeodepth of Sites 1052, 1050 and 1049 as middle bathyal $(600-1000 \mathrm{~m})$, lower bathyal $(1000$ $2000 \mathrm{~m}$ ) and lower bathyal $(1000-2000 \mathrm{~m})$, respectively. Site 1049 is deepest and is situated approximately $10 \mathrm{~km}$ downslope from Site 1050 on the Blake Nose. The following samples were included in the faunal palaeobathymetrical comparison: the five samples of Hole $1050 \mathrm{~B}$ from the $A$. mayaroensis Zone; the five samples of Hole 1049B that derive from the $R$. fructicosa-A. mayaroensis zones; and the nine samples of Hole 1052E that belong to the $R$. fructiocosa and $A$. mayaroensis zones. It is interesting to note that cytherurids (Eucytherura, Hemiparacytheridea) are relatively diverse in Hole $1052 \mathrm{E}$, but are either very rare (Eucytherura sp. 7 in Hole 1050C) or not recorded in the deeper Holes 1050C and 1049B (Tables 2-4). The deep-water genus Cardobairdia and the genus Pterygocythere were recorded in Holes $1050 \mathrm{C}$ and 1049B, but not in Hole 1052E.

The mean OVAR, the mean number of taxa and the mean number of specimens were calculated for the late Maastrichtian of each of Holes 1049B, 1050C and 1052E. Each of these parameters is highest in Hole 1052E and lowest in Hole 1049B, and are thus negatively correlated with palaeodepth (Figs 3AC). The palaeobathymetrical differences in OVAR and abundance (number of specimens) are probably not explained in terms of the effect of dilution of the ostracods by a higher sedimentation rate at greater depths. Norris et al. (1998) estimated the mean sedimentation rate for the Maastrichtian of Sites 1052,1050 and 1049 to be $2.2,1.7$ and $0.36 \mathrm{~cm} / \mathrm{kyr}$, respectively. Thus there is also a negative correlation between the sedimentation rate and the palaeodepth. Alternatively, it may be suggested that the winnowing action of bottom currents may be responsible for the lower abundance of ostracods at the deeper sites. There is, however, no evidence of differential assemblage sorting among the various sites as the ontogenetic distribution of the various ostracod species are similar at all sites.

Hole $1052 \mathrm{E}$ and $1050 \mathrm{C}$ are both dominated by the genera Cytherella, Krithe and Argilloecia (Tables 2 and 3). The most dominant species of Hole 1049B are Cytherella spp. (Table 4). Figure $3 \mathrm{D}$ shows the variation in the relative abundance of the most dominant species among the three holes. There is a greater dominance from the sum of the three dominant genera Cytherella, Krithe and Argilloecia in the late Maastrichtian of Hole $1050 \mathrm{C}$ than in Hole 1052E. The observed increase in dominance with an increase in palaeodepth is further noted for the genus Cytherella. The relative abundance of Cytherella is approximately $30 \%$ in Hole $1052 \mathrm{E}$ and approximately $50 \%$ in Holes 1050C and 1049B (Fig. 3D). An increase in dominance and a decrease in diversity generally imply increased stress levels. The higher dominance, particularly by Cytherella at the deeper sites, may possibly be explained in terms of environmental stress related to low oxygen content. According to Whatley (1991), Boomer \& Whatley (1992) and Whatley et al. (1994), cytherellids may flourish under low oxygen conditions (contrary to many other ostracod taxa) due to their filter-feeding habit in that they manage to obtain a greater volume of water which they circulate 

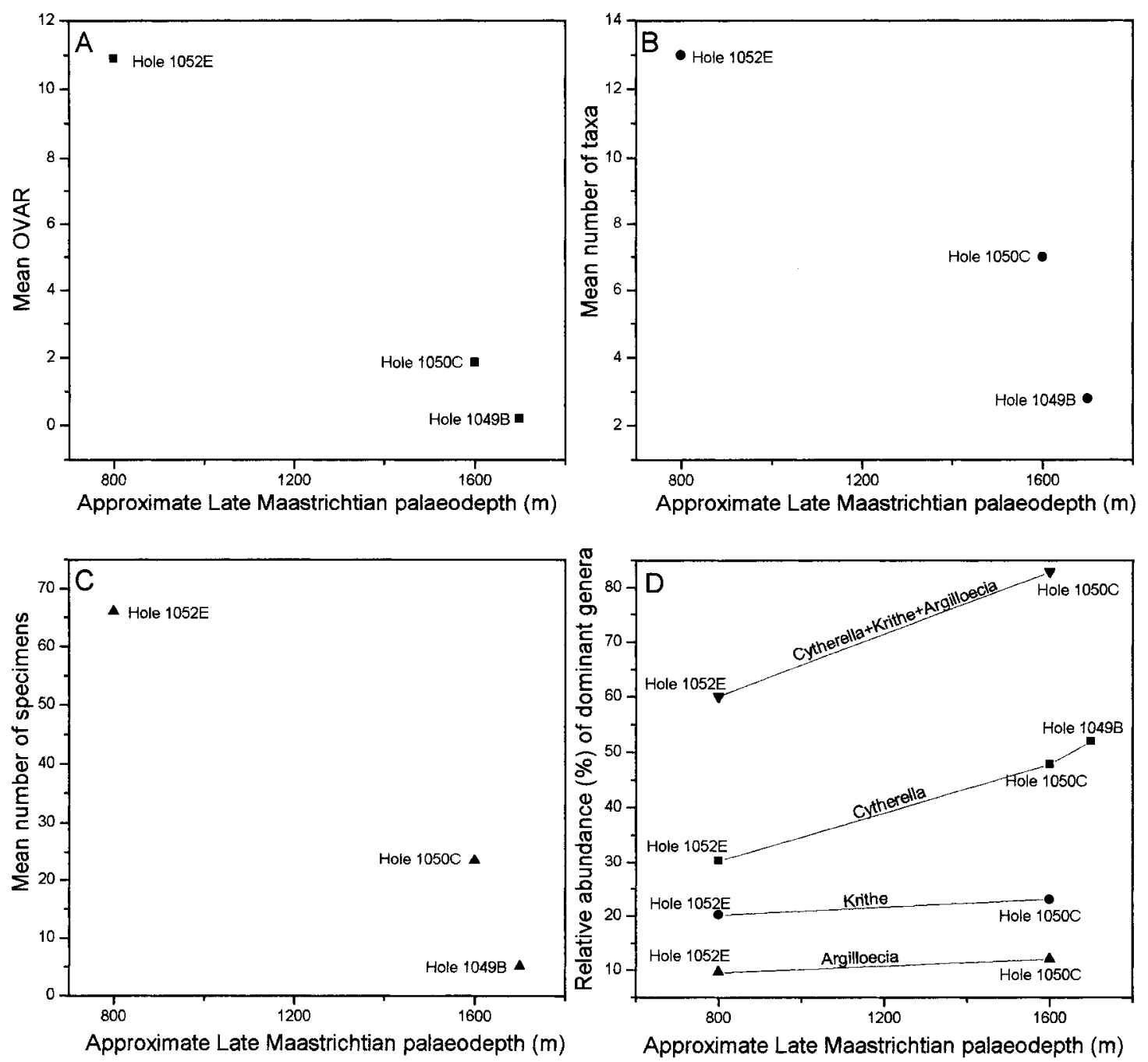

Fig. 3. Palaeobathymetric analysis for the Late Maastrichtian of the nine samples from the $R$. fructicosa and $A$. mayaroensis Zones of Hole $1052 \mathrm{E}$, the five samples from the $A$. mayaroensis Zone of Hole $1050 \mathrm{C}$ and the five samples from the $R$. fructicosa-A. mayaroensis zones of Hole $1049 \mathrm{~B}$. (A) Mean ostracod valve accumulation rate (OVAR in number of specimens $/ \mathrm{cm}^{2} / \mathrm{ka}$ ) (for each hole) plotted against palaeodepth. (B) Mean number of species/ taxa (for each hole) plotted against palaeodepth. (C) Mean number of specimens for each hole plotted against palaeodepth. (D) Mean relative abundance of the dominant genera Cytherella, Krithe and Argilloeca (for the three holes) plotted against palaeodepth.

across their respiratory surface. That the oxygen content was relatively low during the Maastrichtian of Sites 1049 and 1050 is consistent with the observations from benthic foraminifers, where the dominance of Nuttalides truempyi and the low numbers of Gavelinella beccariformis may indicate that the benthic community was indeed influenced by low oxygen, warm, saline, deep water circulation (Norris et al., 1998). Thus it is possible that the differences in OVAR among the three holes are largely related to oxygen concentrations at the sediment-water interface.

There may be other explanations that possibly tie together the observed palaeobathymetric differences in species composition, OVAR, number of species and number of specimens among the various sites investigated, related to, for example, palaeoproductivity and palaeobathymetric differences in food supply and sediment characteristics.

\section{PALAEOBIOGEOGRAPHY OF LATE CRETACEOUS DEEP-SEA OSTRACODS IN THE ATLANTIC AND SOUTHERN OCEANS}

Table 5 lists previous records of the various ostracod genera identified from the Maastrichtian of the present sites studied. The previous records relate to studies of Campanian-Maastrichtian deep-sea ostracods from the North and South Atlantic and from the Southern Ocean and off southeast Africa (see Benson, 1975, 1977; Damotte, 1979, 1988; Dingle, 1981; Swain, 1973, 1978, 1983; Majoran et al., 1997, 1998; Majoran \& Widmark, 1998). The comparison with Dingle (1981) relates only to those species from his assemblages recovered from samples with an estimated palaeodepth $>500 \mathrm{~m}$. The following taxonomic interpretations are presently made: Neocythere sp. 19 in Damotte, 1988 belongs to Paraphysocythere Dingle, (1969); Bythocypris of Sites 689 and 698 in Majoran et al. (1997) and 
Table 5. Palaeobiogeographical distribution of ostracod genera recorded/identified from the Maastrichtian of ODP Sites 1049 , 1050 and 1052 compared with previous records of Campanian-Maastrichtian deep-sea ostracods from the Atlantic, Southern Oceans and off southeast Africa.

\begin{tabular}{|c|c|c|c|c|c|c|c|c|c|c|}
\hline $\begin{array}{l}\text { Ocean: } \\
\text { Genus/location: site } \\
\text { and/or reference }\end{array}$ & (1) & (2) & (3) & (4) & $\begin{array}{l}\text { Sites } \\
525-29^{(5)}\end{array}$ & $\begin{array}{l}\text { Site } \\
327^{(5)}\end{array}$ & $\begin{array}{l}\text { Site } \\
356^{(5)}\end{array}$ & $\begin{array}{l}\text { Site } \\
698^{(5)}\end{array}$ & $\begin{array}{l}\text { Southern } \\
\text { Ocean } \\
\text { Site } \\
689^{(5,6)}\end{array}$ & $\begin{array}{l}\text { SE } \\
\text { Africa } \\
(7)\end{array}$ \\
\hline \multicolumn{11}{|l|}{ Abyssobairdia? } \\
\hline Abyssocypris & & & & & & & & $\mathrm{X}$ & $\mathrm{X}$ & $\mathrm{X}$ \\
\hline Aversovalva & & $\mathrm{X}$ & & & $\mathrm{X}$ & $\mathrm{X}$ & $\mathrm{X}$ & & $\mathrm{X}$ & \\
\hline Bairdia & & & & $\mathrm{X}$ & $x$ & & $x$ & $\mathrm{X}$ & $\mathrm{X}$ & \\
\hline 'Brachycythere' & & $\mathrm{X}$ & $\mathrm{X}$ & & & & & & & $\mathrm{X}$ \\
\hline Bythoceratina & $\mathrm{X}$ & & $\mathrm{X}$ & & & & & & & \\
\hline \multirow{2}{*}{\multicolumn{11}{|c|}{ Cardobairdia }} \\
\hline & & & & & & & & & & \\
\hline Cytherella & $\mathrm{X}$ & $\mathrm{X}$ & $\mathrm{X}$ & $\mathrm{X}$ & $\mathrm{X}$ & & $\mathrm{X}$ & $\mathrm{X}$ & $X$ & $\mathrm{X}$ \\
\hline Imhotepia & & & $\mathrm{X}$ & & & & & & & \\
\hline Krithe & & & & $\mathrm{X}$ & $X$ & & $\mathrm{X}$ & & $\mathrm{X}$ & $\mathrm{X}$ \\
\hline Macrocypris & & & & $\mathrm{X}$ & & & $\mathrm{X}$ & & $\mathrm{X}$ & \\
\hline Mayburya & & & & & $\mathrm{X}$ & & & & & \\
\hline \multicolumn{11}{|l|}{ Palmoconcha } \\
\hline Paracypris & & $\mathrm{X}$ & & & & & & & $\mathrm{X}$ & $\mathrm{X}$ \\
\hline Paraphysocythere & & $\mathrm{X}$ ? & & & $X$ & $\mathrm{X}$ & & & & \\
\hline Phacorhabdotus & & $X$ & $\mathrm{X}$ & $\mathrm{X}$ & $X$ & $\mathrm{X}$ & $\mathrm{X}$ & $\mathrm{X}$ & $\mathrm{X}$ & \\
\hline \multicolumn{11}{|l|}{ Platyleberis } \\
\hline \multicolumn{11}{|l|}{ Propontocypris? } \\
\hline \multicolumn{11}{|l|}{ Pterygocythereis } \\
\hline Semicytherura & & & & & & & & & & \\
\hline
\end{tabular}

(1) Damotte (1979), (2) Damotte (1988), (3) Swain (1978, 1983), (4) Benson (1975, 1977), (5) Majoran et al. (1997, 1998), (6) Majoran \& Widmark (1998) and (7) Dingle (1981).

Majoran et al. (1998) belongs to Abyssocypris van den Bold, 1974; Phacorhabdotus aff. marssoni (Bonnema) in Swain (1978) belongs to Imhotepia Gründel, 1969, and Bythocypris richardsbayensis Dingle, 1981 belongs to Abyssocypris van den Bold, 1974.

Of the 28 genera listed in Table 5, eight have been previously reported from the Campanian-Maastrichtian of the North Atlantic, 17 from the South Atlantic, 14 from the Southern Ocean and 8 from off Southeast Africa. The relatively few ostracod genera, in common with previous studies of the Late Cretaceous North Atlantic, is most certainly due to the limited material published from this region (Damotte, 1979, 1988; Swain, 1978, 1983). It is, however, interesting to note and focus on the relatively large number of genera in common with a single site from a high southern latitude, i.e. Site 689 on the Maud Rise (palaeolatitude $c .70^{\circ} \mathrm{S}$; palaeodepth $c .1200 \mathrm{~m}$, see Zachos \& Arthur, 1986; Thomas, 1990) in the Southern Ocean (Majoran et al., 1997; Majoran \& Widmark, 1998). Of the 14 genera in common between Site 689 and the present sites, particularly Argilloecia, Cytherella, Krithe and Eucythere appear to be relatively abundant at both locations. Abyssocypris and Dutoitella are more common at Site 689 (Majoran et al., 1997;
Majoran \& Widmark, 1998). In the present study of the palaeobiogeography of Late Cretaceous deep-sea ostracods of the Atlantic and Southern Oceans, it must be emphasized that this is a comparison of the data from the present Blake Nose sites and existing information extracted from the references given in Table 5. In this comparison, the genera Cardobairdia, Imhotepia, Palmoconcha, Platyleberis, Propontocypris?, Pterygocythereis and Semicytherura were found only in the present Blake Nose sites (Imhotepia also from Hole 392A in the Western North Atlantic; see Swain, 1978) and may tentatively be suspected to have a rather restricted low latitudinal distribution in the Late Cretaceous deep sea, as far as can be judged from the present restricted comparison. This concerns also Bythoceratina, which is restricted to the North Atlantic (Table 5). Agulhasina, Ginginella and Pennyella seem to be confined to high latitudes in the South Atlantic (see Majoran et al., 1998; Majoran \& Widmark, 1998). Remarkable is the presence of the thermophillic genus Cytherelloidea at Site 689 (Majoran et al., 1997), in contrast with its absence at mid-latitude sites in the South Atlantic (Majoran et al., 1997, 1998) and from the present sites. This may be one example of ostracod taxa that have largely changed their geographical distribution in the deep sea since the 
Late Cretaceous. It is, however, important to point out that the faunal differences and similarities among the various sites compared may not only be due to palaeogeography. Palaeoceanographical aspects such as the oxygen content of various water masses have not been analysed in this section, but are also most certainly important as the results of the study of the present sites seem to show.

\section{DISCUSSION}

The replacement of the depleted ostracod assemblage of the $G$. falsostuarti-G. gansseri zones by the generally richer and more diversified ostracod assemblage of the $R$. fructicosa and $A$. mayaroensis zones in Hole 1052E occurs near the top of magnetostratigraphic subchron C31R (see Table 2). The replacement seems to post-date the short-lived global palaeoceanographic episode observed in southern high latitudes in the early Maastrichtian between about 71 and $70 \mathrm{Ma}$ (see MacLeod, 1994). The boundary between subchrons $C 31 R$ and $C 31 N$ is dated to $68.657 \mathrm{Ma}$ (Gradstein et al., 1994).

It is important to note that the replacement of the ostracod assemblages seems to coincide with the disappearance of inoceramids. Inoceramid prisms occur in samples 1052E-35$1 \mathrm{R}, 110-113 \mathrm{~cm}$ to $1052 \mathrm{E}-29 \mathrm{R}-1,121-125 \mathrm{~cm}$, but were not found in samples $1052 \mathrm{E}-27 \mathrm{R}-1,98-102 \mathrm{~cm}$ to $1052 \mathrm{E}-20 \mathrm{R}-1$, $100-103 \mathrm{~cm}$ (Norris et al., 1998). According to MacLeod (1994), inoceramids were adapted to life in warm, oxygen-deficient conditions on a substrate which had a low population of burrowing organisms and few or no shell-crushing predators. Their extinction was possibly a consequence of the global change in oceanic circulation during which warm, oxygen-poor bottom water was replaced by more vigorously circulating, cool, oxygenated Antarctic bottom water (MacLeod, 1994). That extinction was also accompanied by an increase in the populations of burrowing organisms. MacLeod (1994) proposed three changes that may have contributed to the paleoceanographical reorganization: (1) the subsidence of topographic barriers in the deeper parts of the Atlantic during the Late Cretaceous that could have created pathways for deep water circulation; (2) a general cooling trend of surface and intermediate waters between 74 and $68 \mathrm{Ma}$ that could have created a source of cold, Antarctic bottom water; and (3) a midMaastrichtian regression that restricted the geographical extent of shallow, low and mid-latitude epicontinental seas that could serve as source regions for the formation of warm, saline bottom waters. A sea-level drop within chron C31R corresponding to the second-order cycle of Haq et al. (1987) is estimated to be $50 \mathrm{~m}$ in sections in Alabama (see Barrera, 1994 and references cited therein).

It is possible that the observed changes in the composition of ostracod assemblages across subchrons $\mathrm{C} 31 \mathrm{R}$ to $\mathrm{C} 31 \mathrm{~N}$ are, in part, due to the global palaeoceanographic changes responsible for the extinction of the inoceramids. A lowering of the sea level across the early and late Maastrichtian boundary may, for example, have resulted in an increase in ventilation and the disappearance of the oxygen minimum zone from the location of Site 1052 and may also explain the increase in OVAR.

\section{ACKNOWLEDGEMENTS}

The present study was supported by grants G-AA/GU 06656-
315 and 316 from the Swedish Natural Science Research Council (NFR). The samples were provided through the assistance of the ODP. The author is a shore-based scientist of Leg $171 \mathrm{~B}$.

\section{Manuscript received 23 June 1998 Manuscript accepted March 1999}

\section{REFERENCES}

Barrera, E. 1994. Global environmental changes preceding the Cretaceous-Tertiary boundary: Early-late Maastrichtian transition. Geology, 22: 877-880.

Barrera, E. \& Huber, B. T. 1990. Evolution of Antarctic waters during the Maastrichtian: foraminifer oxygen and carbon isotope ratios, Leg 113. Proceedings of the Ocean Drilling Program, Scientific Results, 113: 813-827.

Barrera, E., Salvin, S. M. \& Thomas, S. 1997. Evidence for thermohaline-circulation reversals controlled by sea-level change in the latest Cretaceous. Geology, 25: 715-718.

Benson, R. H. 1975. The origin of the psychrosphere as recorded in changes of deep-sea ostracode assemblages. Lethaia 8: 69-83.

Benson, R. H. 1977. The Cenozoic Ostracode faunas of the Sao Paulo Plateau and the Rio Grande Rise (DSDP Leg 39, Sites 356 and 357). Initial Reports of the Deep Sea Drilling Project, 39: 869-883.

Benson, R. H., Chapman, R. E. \& Deck, L. T. 1984. Paleoceanographic events and deep-sea Ostracodes. Science 224: 1334-1336.

Benson, R. H., Chapman, R. E. \& Deck, L. T. 1985. Evidence from the Ostracoda of major events in the South Atlantic and world-wide over the past 80 million years. In Hsü, K. J. \& Weissert, H. J. (Eds), South Atlantic Paleoceanography. Cambridge University Press, Cambridge: 325-350.

Boomer, I. D. \& Whatley, R. C. 1992. Ostracoda and dysaerobia in the Lower Jurassic of Wales: the reconstruction of past oxygen levels. Palaeogeography, Palaeoclimatology, Palaeoecology, 99: 373-379.

Damotte, R. 1979. Cretaceous ostracodes of IPOD Leg 48 (Holes 400 , 400A, 401, and 402A). Initial Reports of the Deep Sea Drilling Project, 48: 363-369.

Damotte, R. 1988. Ostracodes crétacés du forage 95, Campagne JOIDES 10, Golfe du Mexique. Cretaceous Research, 9: 159-170.

Dingle, R. V. 1981. The Campanian and Maastrichtian Ostracoda of south-east Africa. Annals of the South African Museum, 85: 1-181.

Gradstein, F. M., Agterberg, F. P., Ogg, J. G., Hardenbol, J., Van Veen, P., Thierry, J. \& Huang, Z. 1994. A Mesozoic time scale. Journal of Geophysical Research, 99: 24051-24074.

Guernet, C. 1982. Contribution a l'étude des faunes abyssales: les ostracodes paléogène du bassins des Bahamas Atlantique Nord (D.S.D.P., Leg. 44). Revue de Micropaléontologie, 25: 40-56.

Haq, B. U., Hardenbol, J. \& Vail, P. R. 1987. Chronology of fluctuating sea levels since the Triassic. Science, 235: 1156-1166.

Herguera, J. C. \& Berger, W. H. 1991. Paleoproductivity from benthic foraminifera abundance: glacial to postglacial productivity changes in the western equatorial Pacific. Geology, 19: 1173-1176.

Huber, B. T. \& Watkins, D. K. 1992. Biogeography of CampanianMaastrichtian calcareous plankton in the region of the Southern Ocean: Paleogeographic and paleoclimatic implications. In Kennett, J. P. \& Warnke, D. A. (Eds), The Antarctic Paleoenvironment: a Perspective on Global Change. Antarctic Research Series, 56: 31-60.

Johnson, C. C. \& Kauffman, E. G. 1990. Originations, radiations and extinctions of Cretaceous rudistid bivalve species in the Caribbean. In Kauffman, E. G. \& Walliser, O. H. (Eds), Extinction Events in Earth History. Springer Verlag, Berlin, Heidelberg: 305-324.

MacLeod, K. G. 1994. Bioturbation, inoceramid extinction, and midMaastrichtian ecological change. Geology 22: 139-142.

MacLeod, K. G. \& Huber, B. T. 1996. Reorganization of deep ocean circulation accompanying a Late Cretaceous extinction event. Nature, 380: $422-425$

MacLeod, K. G., Huber, B. T. \& Ward, P. D. 1996. The biostratigraphy and paleogeography of Maastrichtian inoceramids. In Ryder, G., Fastowsky, D. \& Gartner, S. (Eds), The Cretaceous-Tertiary Event and Other Catastrophes in Earth History. Geological Society of America, Special Paper, 307: 361-373 
Majoran, S. \& Widmark, J. G. V. 1998. Response of deep-sea ostracod assemblages to Late Cretaceous palaeoceanographical changes: ODP Site 689 in the Southern Ocean. Cretaceous Research, 19: 843-872.

Majoran, S., Widmark, J. G. V. \& Kucera, M. 1997. Palaeoecological preferences and geographical distribution of late Maastrichtian deepsea ostracodes in the South Atlantic. Lethaia, 30: 53-64.

Majoran, S., Kucera, M. \& Widmark, J. G. V. 1998. Maastrichtian deepsea ostracods from DSDP/ODP Sites 327, 356, 525, 527, 528, 529, and 698 in the South Atlantic. Revista Española de Micropaleontologia, 30: $59-73$.

Naidu, P. D. \& Malmgren, B. A. 1995. Do benthic foraminifer records represent a productivity index in oxygen minimum zone areas? An evaluation from the Oman Margin, Arabian Sea. Marine Micropaleontolology, 26: 49-55.

Norris, D. J., Kroon, D., et al. 1998. Sites 1049-1052. Proceedings of the Ocean Drilling Program, Initial Reports, 171: 47-320.

Saltzman, E. S. \& Barron, E. J. 1982. Deep circulation in the Late Cretaceous: oxygen isotope paleotemperatures from Inoceramus remains in D.S.D.P. cores. Palaeogeography, Palaeoclimatology, Palaeoecology, 40: 167-181.

Swain, F. M. 1973. Upper Cretaceous Ostracoda from the northwestern Pacific Ocean. Journal of Paleontology 47: 711-714.
Swain, F. M. 1978. Notes on Cretaceous Ostracoda from DSDP Leg 44, Sites 390 and 392. Initial Reports of the Deep Sea Drilling Project, 44: 921-937.

Swain, F. M. 1983. Cretaceous Ostracoda from DSDP and IPOD DeepSea Drilling Sites. In Maddocks, R. F. (Ed.), Applications of Ostracoda. Department of Geosciences, University of Houston: 520528.

Thomas, E. 1990. Late Cretaceous through Neogene deep-sea benthic foraminifers (Maud Rise, Weddel Sea, Antarctica). Proceedings of the Ocean Drilling Program, Scientific Results, 113: 571-594

Van den Bold, W. A. 1974. Taxonomic status of Cardobairdia (Van den Bold, 1960) and Abyssocypris n. gen.: two deepwater ostracode genera of the Caribbean Tertiary. Geoscience and Man, 6: 65-79.

Whatley, R. 1991. The platycopid signal: a means of detecting kenoxic events using Ostracoda. Journal of Micropalaeontology, 10: 181-185.

Whatley, R. C., Arias, C. F. \& Comas-Rengifo, M. J. 1994. The use of Ostracoda to detect kenoxic events: a case history from the Spanish Toarcian. Geobios, 17: 733-741.

Zachos, J. C. \& Arthur, M. A. 1986. Paleoceanography of the Cretaceous/Tertiary event: inferences from stable isotopic and other data. Paleoceanography, 1: 5-26. 